\title{
Pengaruh Model Pembelajaran SAVI Bermuatan Peta Pikiran Terhadap Kreativitas dan Penguasaan Kompetensi Pengetahuan IPA Siswa
}

\author{
*Gusti Ayu Gita Cemara1, Dewa Nyoman Sudana ${ }^{2}$ \\ ${ }^{12}$ Pendidikan Guru Sekolah Dasar, Fakultas Ilmu Pendidikan, Universitas Pendidikan Ganesha Singaraja, Indonesia
}

\author{
A R T I C L E I N F O \\ Article history: \\ Received 10 May 2019 \\ Received in revised form \\ 10 June 2019 \\ Accepted 15 July 2019 \\ Available online 29 August \\ 2019

\begin{tabular}{l}
\hline Kata Kunci: \\
kreativitas, SAVI, peta \\
pikiran. \\
Keywords: \\
creativity, SAVI, mind map.
\end{tabular}

\begin{abstract}
A B S T R A K
Penelitian ini bertujuan untuk mengetahui 1) pengaruh model pembelajaran SAVI bermuatan peta pikiran terhadap kreativitas, 2) pengaruh model pembelajaran SAVI bermuatan peta pikiran terhadap penguasaan kompetensi pengetahuan IPA siswa, secara simultan antara kreativitas dan penguasaan kompetensi pengetahuan IPA siswa. Jenispenelitian ini merupakan quasi experiment dengan desain non equivalent post-tes only control grup. Jumlah populasi dalam penelitian ini adalah 132 orang dan sampel penelitian berjumlah 58 orang yang diambil dengan teknik simple random sampling. Data kreativitas siswa dikumpulkan dengan metode non tes berupa lembar unjuk kerja dan data penguasaan kompetensi pengetahuan IPA dikumpulkan dengan metode tes pilihan ganda. Data dianalisis dengan statistik deskriptif dan statistik inferensial (manova). Hasil penelitian menunjukkan bahwa: 1) terdapat pengaruh yang signifikan model pembelajaran SAVI bermuatan peta pikiran terhadap kreativitas siswa kelas $\mathrm{V}, 2$ ) terdapat pengaruh
\end{abstract} yang signifikan model pembelajaran $S A V I$ bermuatan peta pikiran terhadap penguasaan kompetensi pengetahuan IPA siswa kelas $\mathrm{V}$ dan 3 ) terdapat pengaruh yang simultan model pembelajaran SAVI bermuatan peta pikiran terhadap kreativitas dan penguasaan kompetensi pengetahuan IPA siswa kelas $V$ didapat $(F=40,257 ; p<0,05)$. Berdasarkan temuan tersebut, dapat disimpulkan bahwa model pembelajaran SAVI bermuatan peta pikiran berpengaruh terhadap kreativitas dan penguasaan kompetensi pengetahuan IPA siswa.

\begin{abstract}
A B S T R A C T
This study conducted because of some problems as follows. The first was lack of creativity, concept and sudents' knowledge toward science. The second was lack of being active in learning process. The third was lack of mastering students' competence. This study aims to figure out the effect of SAVI learning model containing mind mapping toward students' creativity, students' science achievment, and simultaneously toward students' creativity and students' science achievement. This study was a quasi experiment which was explored by using non equivalent post-test only control group design. The population were 132 students and the samples were 58 students which were selected using simple random sampling. Students' creativity data was collected by using students' activation sheet. Meanwhile students' science achievement was colleted by using multiple choice tests. The data analyzed by descriptive statistics and inferential statistics (manova). The result of the study showed that: First, there was significant improvement to fifth grade students' creativity which was taught by using SAVI learning model, Second, there was significant effect to the fifth grade students' science achievement which was taught by using SAVI learning model, Third, there was simultaneous and significant improvement to the fifth grade students' creativity and achievement which was taught by SAVI learning model, it was proven by $(F=40,257 ; p<0,05)$. Based on those findings, it can be concluded that SAVI learning model containing mind map affects positively toward students' creativity and sudents' science achievement.
\end{abstract}

Copyright () Universitas Pendidikan Ganesha. All rights reserved. 


\section{Pendahuluan}

IPA merupakan salah satu kompetensi pokok yang ada di sekolah dasar. IPA merupakan "ilmu pengetahuan yang mengkaji gejala-gelaja dalam alam semesta" (Ayu et al., 2016). IPA sebagai disiplin ilmu disebut juga sebagai produk IPA, sedangkan produk tidak dapat dipisahkan dari hakikatnya sebagai proses. Produk IPA merupakan fakta-fakta, konsep-konsep, prinsip-prinsip, serta teori-teori yang diperoleh melalui penelitian yang disebut metode ilmiah. Dalam kompetensi IPA seorang guru diharapkan mampu mengajak anak didiknya memanfaatkan alam sekitar sebagai sumber belajar. Selain itu, kompetensi IPA disekolah dasar bisa memberikan kesempatan siswa untuk merancang serta menemukan sesuatu secara mandiri dan bermakna dengan memanfaatkan alam yang ada di lingkungan sekolah sebagai media nyata yang digunakan untuk belajar. Penggunaan alam sebagai media nyata diyakini mampu membuat siswa lebih aktif dan kreatif untuk melakukan percobaan di alam atau lingkungan sekolah.

Namun berdasarkan observasi ditemukan berbagai hambatan dalam pembelajaran IPA di dalam kelas. Banyak guru mengalami masalah dalam proses pembelajaran IPA. Pembelajaran IPA masih berorientasi pada guru sehingga guru belum mampu menciptakan pembelajaran secara optimal. Selain itu dalam proses pembelajaran guru belum menampakan komunikasi multi arah, baik guru dengan siswa, siswa dengan guru dan siswa dengan siswa. Sehingga, siswa kurang diberikan kesempatan untuk membangun pengetahuan sendiri melalui kegiatan pembelajaran yang dilaksanakan sehingga dalam prosesnya kreativitas siswa menjadi rendah. Padahal kreativitas sangat penting dalam memahami suatu pelajaran atau memaknai dari semua kegiatan yang dilakukan (Budiarti, 2015). Hasilnya penguasaan kompetensi siswa IPA menjadi rendah. Dari hasil observasi di perkuat dengan hasil wawancara dengan beberapa wali kelas V di Gugus Singasari terdapat permasalahan yaitu, (1) konsep dan pengetahuan siswa tentang pembelajaran IPA masih kurang, (2) siswa kurang aktif serta kurang percaya diri dalam menyampaikan ide atau pendapat dalam proses kegiatan belajar mengajar, (3) kurangnya kemampuan siswa dalam mengaplikasikan pembelajaran IPA yang mereka dapatkan di kelas ke dalam permasalahan yang mereka temui sehari-hari (4) siswa jarang melakukan praktek langsung hal itu menyebabkan kurangnya kreativitas siswa dalam mengasah kemampuannya. Siswa jarang melakukan kegiatan praktek dikarenakan alat dan bahan yang kurang memadai, serta membutuhkan waktu yang cukup lama.

Dari permasalahan di atas dapat diketahui bahwa penguasaan kompetensi pengetahuan IPA dan kreativitas siswa cenderung kurang dapat dipecahkan dengan menggunakan metode dan model pembelajaran yang bervariasi. Guru juga masih kurang memahami karakteristik siswa, sehingga tidak sesuai dengan hakikat pembelajaran IPA di Sekoah Dasar. Untuk mengatasi masalah tersebut banyak hal yang bisa dilakukan, seperti menggunakan berbagai model pembelajaran. Salah satu model pembelajaran yang digunakan untuk mengatasi masalah rendahnya kreativitas dan penguasaan komptetensi pengetahuan IPA siswa adalah dengan menggunakan model pembelajaran SAVI. Model pembelajaran SAVI adalah "model pembelajaran yang menekankan bahwa belajar haruslah memanfaatkan semua alat indera yang dimiliki siswa" (Aris, 2014). Dengan adanya model pembelajaran SAVI, siswa dituntut aktif dalam belajar dan mengembangkan nilai karakter pada dirinya sedangkan guru hanya berperan sebagai fasilitator dan moderator (Atmaja, 2017). Selain itu model pembelajaran SAVI mempunyai beberapa keunggulan. Adapun keunggulam dari model pembelajaran SAVI yaitu sebagai berikut, (1) membangkitkan kecerdasan terpadu siswa, (2) siswa membangun sendiri pegetahuannya, (3) memupuk kerjasama karena siswa yang lebih pandai diharapkan dapat membantu yang kurang pandai, (4) memunculkan suasana belajar yang lebih baik, menarik, dan efektif, (5) mampu membangkitkan kreativitas dan (6) meningkatkan kemampuan psikomotor siswa serta siswa akan lebih termotivasi untuk belajar lebih baik.

Selain menggunakan model pembelajaran, perlu juga adanya suatu media pembelajaran yang membantu siswa merangsang minat dan daya tarik untuk mengikuti proses pembelajaran sehingga kegiatan pembelajaran menjadi menyenangkan. Salah satu media pembelajaran yang dapat digunakan adalah peta pikiran. (Widura, 2016) menyatakan bahwa "peta pikiran dalah suatu teknis grafis yang memungkinkan siswa untuk mengeksplorasi seluruh Peta pikiran merupakan salah satu teknik yang cocok untuk membantu daya ingat, karena peta pikiran adalah pemetaan pikiran yang memuat kata kunci suatu topik. Selain itu dalam membuat peta pikiran diperlukan sebuah kreativitas. Kreativitas merupakan "salah satu kebutuhan pokok manusia, yaitu kebutuhan akan perwujudan diri (aktualisasi diri) dan merupakan kebutuhan paling tinggi bagi manusia" (Simatupang, 2016). Kreativitas sangat dibutuhkan agar peta pikiran yang dibuat menarik dan mampu digunakan dengan baik.

Dipilihnya model pembelajaran SAVI bemuatan peta pikiran dikarenakan model pembelajaran ini melibatkan keempat unsur dari SAVI yaitu somatic, audiotory, visual, dan intelektual dengan dipadukan menggunakan peta pikiran yang akan mempermudah siswa dalam proses pembelajaran. Dalam 
pembelajaran ini, siswa diharapkan belajar menggunakan seluruh alat indera yang dimiliki dan aktif dalam kegiatan pembelajaran sehingga guru tidak lagi berfungsi sebagai pemberi ilmu, namun lebih sebagai fasilitator dan mediator. Hal ini sesuai dengan hakikat IPA sebagai produk dan proses yang tidak hanya merupakan kumpulan pengetahuan atau fakta-fakta tetapi juga mempelajari suatu cara kerja, cara berpikir dan cara memecahkan suatu masalah. Selain itu, model pembelajaran SAVI bermuatan peta pikiran juga sesuai dengan perkembangan kognitif siswa yang berada pada tahapan operasional konkrit. Oleh karena itu, guru harus bisa menyesuaikan cara mengajar dengan kondisi siswa, karena setiap siswa memiliki cara belajar dan memiliki karakteristik yang berbeda-beda.

Model pembelajaran SAVI akan berdampak positif dalam proses pembelajaran dilihat dari penelitian yang dilakukan oleh Yudiari 2015, menunjukkan bahwa terdapat perbedaan yang signifikasn hasil belajar IPA antara kelompok siswa yang dibelajarkan dengan model pembelajaran SAVI berbantuan media mind mapping dengan kelompok siswa yang dibelajarkan dengan menggunkan model pembelajaran konvensional pada siswa kelas V Gugus II Kecamatan Mendoyo. Berdasarkan uraian di atas, maka tujuan penelitian ini yaitu 1) Untuk mengetahui pengaruh yang signifikan model pembelajaran SAVI bermuatan peta pikiran terhadap kreativitas siswa kelas V SD Gugus Singasari Kecamatan Pekutatan Tahun Pelajaran 2018/2019. 2) Untuk mengetahui pengaruh yang signifikan model pembelajaran SAVI bermuatan peta pikiran terhadap penguasaan kompetensi IPA siswa kelas V SD Gugus Singasari Kecamatan Pekutatan Tahun Pelajaran 2018/2019. 3) Untuk mengetahui pengaruh yang simultan model pembelajaran SAVI bermuatan peta pikiran terhadap kreativitas dan penguasaan kompetensi IPA siswa kelas V SD Gugus Singasari Kecamatan Pekutatan Tahun Pelajaran 2018/2019.

\section{Metode}

Penelitian ini merupakan penelitian eksperimen semu (quasi experiment) Penelitian eksperimen semu merupakan penempatan subjek ke dalam kelompok yang dibandingkan tidak dilakukan secara acak melainkan sudah ada dalam kelompok yang dibandingkan sebelum diadakannya penelitian. Eksperimen semu tidak memungkinkan untuk mengontrol variabel-variabel luar yang mempengaruhi pelaksanaan eksperimen. Sehingga rancangan penelitian yang digunakan adalah non equivalent post-test only control group design. Kelompok eksperimen dalam penelitian ini dikenakan perlakuan dengan menggunakan model pembelajaran SAVI bermuatan peta pikiran dan kelompok kontrol dikenakan perlakuan dengan tidak menggunakan model pembelajaran SAVI bermuatan peta pikiran yang dilakukan dalam jangka waktu tertentu. Kedua kelompok ini kemudian akan dikenakan pengukuran yang sama. Perbedaan hasil pengukuran yang akan timbul dianggap sumber dari variabel perlakuan. Sesuai dengan batasan masalah dan tujuan penelitian, populasi dalam penelitian ini adalah siswa kelas V SD Gugus Singasari Kecamatan Pekutatan Tahun Pelajaran 2018/2019. Sebelum mencari kelas eksperimen dan kelas kontrol dilakukan uji kesetaraan, dalam penelitian ini uji kesetaraan menggunakan Anava Satu Jalur. Setelah melakukan uji kesetaraan dilanjutkan menentukan sampel penelitian. Untuk menentukan kelas eksperimen dan kelas kontrol dilakukan teknik simple random sampling (random kelas). Berdasarkan pengundian yang telah dilakukan didapatkan hasil bahwa kelas V SD N 2 Medewi sebagai kelas eksperimen, sedangkan kelas V SD N 3 Medewi sebagai kelas kontrol. Dalam sebuah penelitian, data merupakan salah satu bagian yang terpenting. Pada penelitian ini metode pengumpulan data yang dilakukan adalah dengan menggunakan unjuk kerja untuk mengetahui kreativitas siswa dan tes objektif untuk melihat penguasaan kompetensi pengetahuan siswa. Adapun tahapan dalam menganalisis data dalam penelitian ini adalah deskripsi data, uji prasyarat analisis (uji prasayarat yang dilakukan adalah uji normalitas sebaran data, uji homogenitas varians, dan uji korelasi antar variabel terikat), dan uji hipotesis. Untuk mendeskripsikan data digunakan statistik deskriptif dan untuk menguji hipotesis sesuai yang diajukan digunakan teknik analisis multivariat (MANOVA).

\section{Hasil dan Pembahasan}

Pengukuran dilakukan setelah kedua kelompok diberikan perlakuan yang berbeda, yaitu SD Negeri 2 Medewi sebagai kelas eksperimen atau kelas yang dibelajarkan dengan menggunakan model pembelajaran SAVI bermuatan peta pikiran. Sedangkan siswa kelas V SD Negeri 3 Medewi sebagai kelas kontrol atau kelas yang tidak dibelajarkan dengan menggunakan model pembelajaran SAVI bermuatan peta pikiran. Kedua kelas sampel diberikan perlakuan sebanyak 7 kali pertemuan dan pertemuan ke-8 diberikan post-test. Analisis data dilakukan pada masing-masing kelas. Adapun hasil analisis data deskriptif disajikan pada Tabel 1 . 
Tabel 1. Analisis data dengan statistik deskriptif

\begin{tabular}{lcccc}
\hline & Variabel & \multicolumn{2}{c}{ A1 } & \multicolumn{2}{c}{ A2 } \\
\cline { 2 - 5 } Statistik & Y1 & Y2 & Y1 & Y2 \\
N & 30 & 28 & 30 & 28 \\
Mean & 83,73 & 74,14 & 89,83 & 74,86 \\
Median & 84,46 & 70,50 & 90,40 & 72,31 \\
Modus & 88,17 & 70,23 & 92,83 & 72,19 \\
Standar Deviasi & 9,65 & 8,86 & 7,06 & 6,67 \\
Varians & 93,20 & 78,49 & 49,80 & 44,45 \\
Range & 38 & 32 & 27 & 27 \\
Minimum & 56 & 56 & 70 & 60 \\
Maksimum & 94 & 88 & 97 & 87 \\
\hline
\end{tabular}

Berdasarkan tabel 1, engujian hipotesis pada penelitian ini dilakukan dengan menggunakan ANAVA A dan multivariat analisis varians (MANOVA). Untuk keperluan ini dilakukan uji persyaratan, yaitu uji normalitas sebaran data, uji homogenitas varians, dan uji korelasi antar variabel terikat. Setelah semua uji prasyarat telah dilakukan maka dilanjutkan dengan uji hipotesis. Terdapat tiga hipotesis yang diajukan dalam penelitian ini. Untuk pengujian hipotesis 1 dan hipotesis 2 menggunakan ANAVA A dan hipotesis 3 menggunakan MANOVA. Hipotesis 0 tidak terdapat pengaruh yang signifikan kreativitas antara siswa yang mengikuti model pembelajaran $S A V I$ bermuatan peta pikiran dengan siswa yang tidak mengikutit model pembelajaran SAVI bermuatan peta pikiran pada siswa kelas V SD Gugus Singasari Kecamatan Pekutatan Tahun Pelajaran 2018/2019. Pengujian hipotesis pertama menggunakan analisis varian satu jalur (ANAVA A). Kriteria yang digunakan adalah dengan membandingkan harga Fhitung dengan Ftabel pada taraf signifikan $5 \%$ dengan db pembilang $(\mathrm{a}-1)$ dan db penyebut $(\mathrm{N}-\mathrm{a})$. Aturan keputusan dalam perhitungan ini adalah jika Fhitung lebih besar dari pada Ftabel, maka H1 diterima dan H0 ditolak yang artinya terdapat perbedaan variabel dependen antar kelompok. Ringkasan hasil uji F dapat dilihat pada ringkasan Tabel 02 di bawah ini.

Tabel 2. Ringkasan Uji F Hipotesis Pertama

\begin{tabular}{lllllll}
\hline $\begin{array}{l}\text { Sumber } \\
\text { Variasi }\end{array}$ & $\mathrm{JK}$ & $\mathrm{Db}$ & $\mathrm{RJK}$ & Fhitung & Ftab (5\%) & Keputusan \\
\hline Antar A & 1954,4 & 1 & 1954,4 & 22,7 & 4,01 & Signifikan \\
Dalam & 4822,22 & 56 & 86,11 & - & - & - \\
Total & 6776,62 & 57 & - & - & - & - \\
\hline
\end{tabular}

Berdasarkan tabel 2 hasil analisis di atas, diperoleh nilai Fhitung $=22,7$ dan Ftabel $(1: 56)(0,05)=$ 4,01. Ini berarti Fhitung > Ftabel $(22,7>4,01)$. Hal ini berarti pula bahwa H0 ditolak dan H1 diterima. Dengan demikian dapat ditarik kesimpulan bahwa terdapat pengaruh yang signifikan kreativitas antara siswa yang mengikuti model pembelajaran SAVI bermuatan peta pikiran dengan siswa yang tidak mengikutit model pembelajaran SAVI bermuatan peta pikiran pada siswa kelas V SD Gugus Singasari Kecamatan Pekutatan Tahun Pelajaran 2018/2019. Hipotesis 0 kedua dalam penelitian ini berbunyi Tidak terdapat pengaruh yang signifikan model pembelajaran SAVI bermuatan peta pikiran dengan siswa yang tidak mengikuti model pembelajaran SAVI bermuatan peta pikiran terhadap Penguasaan Kompetensi Pengetahuan IPA Siswa kelas V SD Gugus Singasari Kecamatan Pekutatan Tahun Pelajaran 2018/2019. Pengujian hipotesis kedua menggunakan analisis varian satu jalur (ANAVA A). Kriteria yang digunakan adalah dengan membandingkan harga Fhitung dengan Ftabel pada taraf signifikan 5\% dengan db pembilang (a-1) dan db penyebut $(\mathrm{N}-\mathrm{a})$. Aturan keputusan dalam perhitungan ini adalah jika Fhitung lebih besar dari pada Ftabel, maka H1 diterima dan H0 ditolak yang artinya terdapat perbedaan variabel dependen antar kelompok. Ringkasan hasil uji F dapat dilihat pada ringkasan Tabel 03 berikut. 
Tabel 3. Ringkasan Uji F Hipotesis Kedua

\begin{tabular}{lllllll}
\hline $\begin{array}{l}\text { Sumber } \\
\text { Variasi }\end{array}$ & $\mathrm{JK}$ & $\mathrm{Db}$ & $\mathrm{RJK}$ & $\mathrm{F}_{\text {hitung }}$ & $\mathrm{F}_{\text {tab }}$ (5\%) & Keputusan \\
\hline Antar A & 3326,21 & 1 & 3326,21 & 70,44 & 4,01 & Signifikan \\
Dalam & 264427 & 56 & 47,22 & - & - & - \\
Total & 5970,48 & 57 & - & - & - & - \\
\hline
\end{tabular}

Berdasarkan tabel 3 hasil analisis di atas, diperoleh nilai Fhitung $=70,44$ dan Ftabel $(1: 56)(0,05)=$ 4,01. Ini berarti Fhitung > Ftabel $(70,44>4,01)$. Hal ini juga berarti pula bahwa H0 ditolak dan H1 diterima. Dengan demikian dapat ditarik kesimpulan bahwa Terdapat pengaruh yang signifikan model pembelajaran $S A V I$ bermuatan peta pikiran dengan siswa yang tidak mengikuti model pembelajaran $S A V I$ bermuatan peta pikiran terhadap Penguasaan Kompetensi Pengetahuan IPA Siswa kelas V SD Gugus Singasari Kecamatan Pekutatan Tahun Pelajaran 2018/2019. Hipotesis 0 ketiga dalam penelitian ini berbunyi Tidak terdapat pengaruh yang simultan model pembelajaran SAVI bermuatan peta pikiran dengan siswa yang tidak mengikuti model pembelajaran SAVI bermuatan peta pikiran terhadap kreativitas dan penguasaan kompetensi IPA siswa kelas V SD Gugus Singasari Kecamatan Pekutatan Tahun Pelajaran 2018/2019. Untuk menguji hipotesis di atas digunakan uji MANOVA. Nilai Fhitung dicari dengan menggunakan bantuan program SPSS. Kriteria yang digunakan adalah jika nilai signifikansi sama atau lebih kecil dari 0,05, maka H0 ditolak. Sebaliknya, jika nilai signifikansi lebih besar 0,05, maka H0 diterima. Ringkasan hasil analisis uji MANOVA dapat dilihat pada Tabel 04 berikut.

Tabel 4. Ringkasan Hasil Analisis MANOVA

\begin{tabular}{lllllll}
\hline $\begin{array}{l}\text { Multivariate Tests } \\
\text { Effect }\end{array}$ & & & & & & \\
& & Value & F & Hypothesis df & Error df & Sig. \\
\hline \multirow{4}{*}{ Intercept } & Pillai's Trace & .995 & $5292.948^{\mathrm{a}}$ & 2.000 & 55.000 & .000 \\
& Wilks' Lambda & .005 & $5292.948^{\mathrm{a}}$ & 2.000 & 55.000 & .000 \\
& Hotelling's Trace & 192.471 & $5292.948^{\mathrm{a}}$ & 2.000 & 55.000 & .000 \\
MODEL_PEMBELAJ & Roy's Largest Root & 192.471 & $5292.948^{\mathrm{a}}$ & 2.000 & 55.000 & .000 \\
ARA & Pillai's Trace & .594 & $40.257^{\mathrm{a}}$ & 2.000 & 55.000 & .000 \\
& Hotelling's Tambda & .406 & $40.257^{\mathrm{a}}$ & 2.000 & 55.000 & .000 \\
$\begin{array}{l}\text { a. Exact statistic } \\
\text { b. Design: Intercept }\end{array}$ & 1.464 & $40.257^{\mathrm{a}}$ & 2.000 & 55.000 & .000 \\
\hline
\end{tabular}

Berdasarkan tabel 4 hasil analisis MANOVA menunjukkan bahwa nilai signifikansi uji Manova melalui Pillai trace, Wilks' Lambda Hotelling's trace dan Roy's largest Root adalah 0,000 dan nilai ini lebih kecil dari 0,05 $(\mathrm{p}<0,05)$. Jadi, H0 ditolak dan H1 diterima. Dengan demikian, dapat disimpulkan bahwa Terdapat pengaruh yang simultan model pembelajaran SAVI bermuatan peta pikiran dengan siswa yang tidak mengikuti model pembelajaran SAVI bermuatan peta pikiran terhadap kreativitas dan penguasaan kompetensi IPA siswa kelas V SD Gugus Singasari Kecamatan Pekutatan Tahun Pelajaran 2018/2019.

Pada penelitian ini yang dibandingkan adalah: (1) model pembelajaran SAVI bermuatan peta pikiran dengan siswa yang tidak mengikuti model pembelajaran $S A V I$ bermuatan peta pikiran terhadap kreativitas, (2) model pembelajaran SAVI bermuatan peta pikiran dengan siswa yang tidak mengikuti dengan model pembelajaran $S A V I$ bermuatan peta pikiran terhadap penguasaan kompetensi pengetahuan IPA siswa, dan 3) secara simultan model pembelajaran SAVI bermuatan peta pikiran dengan siswa yang tidak mengikuti dengan model pembelajaran SAVI bermuatan peta pikiran terhadap kreativitas dan penguasaan kompetensi pengetahuan IPA siswa.

Berdasarkan penelitian yang telah dilakukan, secara deskriptif kreativitas dan penguasaan kompetensi pengetahuan IPA siswa kelas V yang mengikuti model pembelajaran SAVI bermuatan peta pikiran memiliki rata-rata skor kreativitas dan penguasaan kompetensi pegetahuan IPA siswa lebih tinggi dari rata-rata skor kreativitas dan penguasaan kompetensi pengetahuan IPA siswa yang tidak mengikuti model pembelajaran SAVI bermuatan peta pikiran. 
Hasil analisis data kreativitas siswa menunjukkan terdapat pengaruh kreativitas siswa yang dibelajarkan dengan model pembelajaran SAVI bermuatan peta pikiran dengan siswa yang tidak dibelajarkan dengan model pembelajaran SAVI bermuatan peta pikiran. hal tersebut terjadi dikarenakan disebabkan oleh beberapa faktor yaitu adanya perbedaan perlakuam pada langkah-langkah pembelajaran dan proses pembelajaran.

Pertama, meningkatnya kreativitas siswa dalam belajar disebabkan karena penerapan model pembelajaran SAVI. Model pembelajaran SAVI mampu memanfaatkan alat indera baik fisik maupun psikis siswa dalam poses pembelajaran. Hal ini dapat dibuktikan melalui kegiatan siswa mendengarkan dengan baik apa yang dijelaskan oleh guru kemudian siswa secara aktif menggali informasi baik melalui diskusi, mengerjakan LKS, membuat peta pikiran, maupun menyampaikan hasil diskusinya. Siswa yang diberikan kesempatan untuk berperan aktif mampu meningkatkan daya kreativitas siswa untuk membuat sesuatu dalam proses pembelajaran sehingga apa yang dipelajarinya menjadi lebih bermakna dan mampu meningkat pengetahuan siswa. Hal ini sesuai dengan pendapat Suherman (Carito, Rohim, 2013) yang menyatakan dengan model pembelajaran SAVI, siswa mempunyai kesempatan untuk berperan aktif dalam proses pembelajaran, sehingga dapat meningkatkan pemahaman konsep dan kreativtas belajar siswa.

Kedua, luasnya cakupan IPA membuat siswa belajar tidak semata-mata hanya mendengar apa yang dijelaskan oleh guru, bertanya, berdiskusi, dan mampu menerapkannya. Hal ini dapat dibuktikan dalam kegiatan pembelajaran yang dilakukan di dalam kelas, siswa tidak hanya mendengarkan apa yang disampaikan oleh guru melainkan siswa dapat melihat apa yang dipelajarinya, kemudian siswa diberikan kesempatan untuk bertanya terkait materi yang dipelajarinya lalu siswa melakukan diskusi kelompok menggali informasi tentang materi yang dipelajarinya lalu menuangkan ke dalam sebuah catatan dalam bentuk peta pikiran yang melatih kreativitas siswa dalam menuangkan ide-ide yang telah dipelajarinya sehingga siswa dengan mudah memahami materi. Selain itu dalam model pembelajaran SAVI dilihat dari Somatic yaitu mengajak siswa bergerak secara fisik dalam pembelajaran. Dilihat dari segi Auditory yaitu belajar dengan berbicara dan mendengarkan. Dilihat dari segi Visual yaitu siswa belajar dengan melihat. Secara Intellectual pembelajaran dengan mengandalkan pemikiran untuk memecahkan permasalahan yang ditemui siswa. Belajar dengan melibatkan semua alat indra yang dimiliki siswa menyebabkan siswa aktif dalam pembelajaran dan motivasi siswa untuk belajar menjadi meningkat. SAVI (Somatic, Auditory, Visual,dan Intellectual) pembelajaran yang harus melibatkan semua alat indra yang dimiliki siswa (Aris, 2014). Disamping itu juga, siswa diberikan kesempatan untuk berbicara atau menyampaikan pendapat dan menanggapi pendapat orang lain. Penjelasan di atas didukung oleh pendapat (Silberman, 2013) yang menyatakan apa yang aku dengar, aku lupa. Apa yang aku dengar dan lihat, aku mengingatnya sedikit. apa yang aku dengar, lihat, dan tanyakan kepada atau diskusikan dengan orang lain, aku mulai memahaminya. Apa yang aku dengar, lihat, diskusikan, dan lakukan, memberiku pengetahuan dan keterampilan. Apa yang aku ajarkan kepada orang lain, aku menguasainya.

Ketiga, melalui model pembelajaran SAVI bermuatan peta pikiran pada tahap penyampaian terlihat dapat menumbuhkan motivasi belajar bagi siswa, membangkitkan ketertarikan siswa saat belajar, dan menumbuhkan kreativitas siswa dalam belajar. Selain menggunakan media peta pikiran, siswa diharapkan mampu membuat peta pikiran yang melibatkan kreativitas siswa agar siswa dapat mengasah kemampuannya untuk dapat berpikir aktif dalam menuangkan ide-ide atau gagasan yang dimilikinya. Melalui membuat peta pikiran siswa akan berkreasi menuangkan imajinasi dan kreativitas yang ada pada otak siswa. Peta pikiran yang dibuat oleh siswa bervariasi sesuai dengan imajinasi yang dituangkan oleh siswa. Hal ini menunjukkan siswa mampu berkreasi dalam menuangkan ide-ide yang ada pada otak siswa, sehingga dengan membuat peta pikiran akan terlihat cara berpikir kreatif siswa, kreativitas siswa, dan nilai estetika siswa. Hal ini senada dengan pendapat (Arini, 2012) yang menyatakan bahwa penggunaan peta pikiran akan menuntun siswa untuk berpikir aktif menuangkan pikiran yang ada pada otak siswa dan menuangkan perasaan yang siswa rasakan.

Hasil analisis data penguasaan kompetensi pengetahuan IPA menunjukkan bahwa terdapat perbedaan hasil belajar IPA siswa antara kelompok siswa yang dibelajarkan dengan model pembelajaran $S A V I$ bermuatan peta pikiran dengan kelompok siswa yang tidak dibelajarkan dengan model SAVI bermuatan peta pikiran. Hal tersebut terjadi yang disebabkan oleh beberapa faktor diantaranya sebagai berikut. Penerapan model pembelajaran SAVI berbantuan peta pikiran menekankan pada keaktifan siswa dalam menemukan pengetahuan dan keterampilan baru secara mandiri melalui tahap persiapan, tahap penyampaian, tahap Pelatihan, dan tahap penampilan.

Pertama, pada tahap persiapan, guru memberikan pertanyaan-pertanyaan yang merangsang siswa untuk mulai berpikir, membangkitkan rasa ingin tahu siswa, dan mengajak siswa terlibat penuh sejak awal pembelajaran sehingga siswa termotivasi untuk mempelajari materi yang akan dibahas. Hal ini juga akan memberikan perasaan positif untuk mengawali pembelajaran sehingga siswa siap dalam mengikuti 
pembelajaran selanjutnya, karena menurut Meier (Yudiari, 2016) langkah awal dalam pembelajaran sangat menentukan proses pembelajaran selanjutnya.

Kedua, pada tahap penyampaian guru membahas materi bersama siswa melalui proses tanya jawab dengan bantuan media peta pikiran. Pembahasan materi dengan proses tanya jawab pada tahap penyampaian dapat melatih kemampuan kognitif siswa karena melalui proses tersebut siswa akan berusaha menggali pengetahuan yang dimilikinya dan mencari berbagai sumber informasi untuk menjawab pertanyaan-pertanyaan guru, bertanya kembali pada guru, dan mengaitkan pengetahuan awalnya dengan pengetahuan baru yang diperoleh selama proses tanya jawab. Dengan demikian pengetahuan dan keterampilan yang diperoleh siswa lebih bermakna dan siswa tidak sekedar pasif menerima informasi dari guru. Penyampaian materi dengan cara yang bermakna melalui proses tanya jawab menciptakan komunikasi dua arah antara guru dan siswa. Hal ini sesuai dengan Meier (Yudiari, 2016) pembelajaran akan terganggu jika pembelajar tidak memperoleh pengetahuan dan keterampilan dengan cara yang bermakna dan melibatkan diri siswa secara penuh. Peta pikiran yang digunakan guru pada tahap penyampaian memuat ide-ide pokok materi pelajaran dan berisi beberapa kolom kosong yang perlu diisi siswa saat proses tanya jawab berlangsung dan pada saat menyimpulkan di akhir pembelajaran. Peta pikiran yang disertai kolom-kolom kosong membuat siswa terlatih untuk menemukan konsep baru dengan cara yang menarik dan tidak tergantung pada guru. Peta pikiran yang digunakan juga berisi gambar-gambar menarik yang relevan dengan materi yang dibahas sehingga mampu memperjelas materi dan membantu siswa memahami apa yang sedang dipelajari yang akan berdampak positif pada pengasaan kompetensi pengetahuan siswa. Hal ini didukung dengan pendapat Buzan (Yudiari, 2016) yaitu, peta pikiran bermanfaat untuk memusatkan perhatian, meningkatkan pemahaman, dan pembelajaran lebih menarik serta mudah diingat.

Ketiga, pada tahap penelitian siswa diajak berdiskusi secara berkelompok berdasarkan materi yang dipelajari, sehingga mampu menumbuhkan rasa ingin tahu siswa terhadap hal yang dipelajari dan siswa akan termotivasi untuk mengikuti proses pembelajaran. Pada tahap ini juga melatih siswa untuk dapat mengemukakan sendiri hasil dari temuannya dengan cara menyajikan hasil diskusi yang telah dilakukan sehingga pembelajaran akan lebih bermakna. Kemudian guru memberikan umpan balik terhadap hasil diskusi yang telah disampaikan siswa baik berupa penguatan ataupun saran-saran untuk perbaikan.

Keempat, pada tahap penampilan siswa dibimbing oleh guru untuk menyimpulkan kegiatan pembelajaran yang telah berlangsung. Siswa juga dituntut untuk membuat rangkuman tentang pembelajaran yang telah dilalui baik berupa peta pikiran sederhana maupun catatan untuk dipelajari di rumah. Kemudian guru memberikan tindak lanjut berupa evalusi untuk mengetahui pemahaman siswa terhadap materi yang telah dipelajari. Evaluasi sangat penting dilakukan karena dari sini guru dapat mengetahui berhasil atau tidaknya suatu proses pembelajaran. Hal ini sejalan dengan pendapat Suwandi (Yudiari, 2016) yaitu, penilaian atau evaluasi merupakan hal yang paling intern dalam proses pembelajaran. Evaluasi merupakan salah satu kegiatan yang harus dilakukan guru dan siswa untuk melihat keberhasilan suatu kegiatan pembelajaran.

Jika dilihat langkah-langkah model pembelajaran SAVI bermuatan peta pikiran yang telah dijabarkan di atas, maka langkah-langkah tersebut sangat sesuai dengan karakteristik pembelajaran IPA yang menekankan pada keaktifan siswa secara mandiri menggali pengetahuannya. Hal ini sesuai dengan pendapat Moh Amin (Dewi, 2013) yang menyatakan, "proses pembelajaran sains/IPA di SD menuntut keterlibatan para peserta didik secara aktif dan bertujuan agar penguasaan dari kognitif, afektif dan psikomotor terbentuk pada diri siswa". Pembelajaran SAVI bermuatan peta pikiran tidak hanya mempersiapkan siswa untuk menerima informasi tetapi siswa juga mencari, menemukan, dan mengkontruksi pengetahuan secara mandiri melalui berbagai kegiatan dalam langkah-langkah pembelajaran. Model pembelajaran SAVI bermuatan peta pikiran yang telah diterapkan memberikan ruang gerak kepada siswa untuk membangun pengetahuannya sendiri dengan aktivitas-aktivitas siswa baik dengan mendengar, berbicara, maupun berbuat melalui lembar kegiatan siswa (LKS), membuat peta pikiran, berdiskusi dan bertanya jawab yang mengutamakan keterlibatan siswa secara langsung yang di dalamnnya memuat kegiatan mencoba, melakukan, dan berlatih. Temuan ini didukung oleh penelitian yang dilakukan oleh, (Haruminati, 2016) dengan temuan yakni terdapat perbedaan yang signifikan hasil belajar IPA antara kelompok siswa yang dibelajarkan dengan model pembelajaran SAVI berbantuan media mind mapping dengan kelompok siswa yang dibelajarkan dengan model pembelajaran konvensional.

Berdasarkan hasil analisis data tentang kreativitas dan penguasaan komepetnsi pengetahuam IPA siswa menunjukkan, terdapat perbedaan secara simultan kreativitas dan penguasaan komepetensi pengetahuam IPA siswa pada kelompok siswa yang dibelajarkan dengan model pembelajaran SAVI bermuatan peta pikiran dengan kelompok siswa yang tidak dibelajarkan dengan model pembelajaran 
SAVI bermuatan peta pikiran. Hal tersebut terjadi yang disebabkan oleh beberapa faktor diantaranya sebagai berikut.

Pertama, meningkatnya kreativitas siswa dalam belajar disebabkan karena penerapan model pembelajaran SAVI. Model pembelajaran SAVI mampu memanfaatkan alat indera baik fisik maupun psikis siswa dalam poses pembelajaran. Hal ini dapat dibuktikan melalui kegiatan siswa mendengarkan dengan baik apa yang dijelaskan oleh guru kemudian siswa secara aktif menggali informasi baik melalui diskusi, mengerjakan LKS, membuat peta pikiran, maupun menyampaikan hasil diskusinya. Hal ini sesuai dengan pendapat Suherman (Carito, Rohim, 2013) yang menyatakan dengan model pembelajaran SAVI, siswa mempunyai kesempatan untuk berperan aktif dalam proses pembelajaran, sehingga dapat meningkatkan pemahaman konsep dan kreativtas belajar siswa.

Kedua, luasnya cakupan IPA membuat siswa belajar tidak semata-mata hanya mendengar apa yang dijelaskan oleh guru, bertanya, berdiskusi, dan mampu menerapkannya. Hal ini dapat dibuktikan dalam kegiatan pembelajaran yang dilakukan di dalam kelas, siswa tidak hanya mendengarkan apa yang disampaikan oleh guru melainkan siswa dapat melihat apa yang dipelajarinya, kemudian siswa diberikan kesempatan untuk bertanya terkait materi yang dipelajarinya lalu siswa melakukan diskusi kelompok menggali informasi tentang materi yang dipelajarinya lalu menuangkan ke dalam sebuah catatan dalam bentuk peta pikiran yang melatih kreativitas siswa dalam menuangkan ide-ide yang telah dipelajarinya sehingga siswa dengan mudah memahami materi yang dipelajari.

Ketiga, melalui model pembelajaran SAVI bermuatan peta pikiran pada tahap penyampaian terlihat dapat menumbuhkan motivasi belajar bagi siswa, membangkitkan ketertarikan siswa saat belajar, dan menumbuhkan kreativitas siswa dalam belajar. Selain menggunakan media peta pikiran, siswa diharapkan mampu membuat peta pikiran yang melibatkan kreativitas siswa agar siswa dapat mengasah kemampuannya untuk dapat berpikir aktif dalam menuangkan ide-ide atau gagasan yang dimilikinya. Melalui membuat peta pikiran siswa akan berkreasi menuangkan imajinasi dan kreativitas yang ada pada otak siswa. Peta pikiran yang dibuat oleh siswa bervariasi sesuai dengan imajinasi yang dituangkan oleh siswa. Hal ini menunjukkan siswa mampu berkreasi dalam menuangkan ide-ide yang ada pada otak siswa, sehingga dengan membuat peta pikiran akan terlihat cara berpikir kreatif siswa, kreativitas siswa, dan nilai estetika siswa. Hal ini senada dengan pendapat (Arini, 2012) yang menyatakan bahwa penggunaan peta pikiran akan menuntun siswa untuk berpikir aktif menuangkan pikiran yang ada pada otak siswa dan menuangkan perasaan yang siswa rasakan.

Keempat dalam kompetensi pengetahuan IPA terdapat beberapa tahapan yang mempengaruhi proses belajar mengajar seperti tahap persiapan, tahap penyampaian, tahap penelitian, dan penampilan. Tahapan-tahapan tersebut menekankan pada keaktifan siswa. Hal ini sesuai dengan pendapat Amin (dalam Dewi, yang menyatakan, "proses pembelajaran sains/IPA di Sd menuntut keterlibatan peserta didik secara aktif dan bertujuan agar penguasaan kognitif, apektif, dan psikomotor terbentuk pada diri siswa".

Hal inilah yang menjadi keunggulan dari model pembelajaran SAVI berbmuatan peta pikiran dibandingkan dengan yang tidak dibelajarkan dengan model pembelajaran SAVI bermuatan peta pikiran. Pembelajaran yang tidak dibelajarkan dengan model pembelajaran SAVI bermuatan peta pikiran yang diterapkan oleh guru membuat siswa menjadi pasif dan mengerjakan apa saja yang di suruh oleh guru. Guru dalam menyampaikan materi pelajaran lebih banyak menggunakan metode ceramah sehingga menyebabkan pembelajaran bersifat teoritis. Selain metode ceramah, guru juga menerapakan metode tanya jawab dan penugasan. Proses tanya jawab yang dilakukan oleh guru tidak banyak memberikan kesempatan kepada siswa untuk melaksanakan tanya jawab multi arah (guru-siswa, siswa-siswa, dan siswa-guru) sehingga siswa tidak dapat mengembangkan kemampuannya dalam menyampaikan pendapat. Hal ini menyebabkan kurangnya kreativitas siswa dalam belajar IPA. Hal ini sesuai dengan pendapat (Putrayasa., 2014) yang menyatakan siswa yang memiliki penguasaan kompetensi pengetahuan rendah lebih menyukai keadaan yang biasa sehingga siswa cenderung tidak aktif dalam proses pembelajaran.

Berdasarkan hasil penelitian yang dilakukan dan diperkuat oleh beberapa pendapat. Dapat dipahami bahwa minat siswa dalam proses pembelajaran meningkat setelah mengikuti model pembelajaran SAVI bermuatan peta pikiran, begitu pula dengan penguasaan kompetensi pengetahuan IPA siswa meningkat setelah mengikuti model pembelajaran SAVI bermuatan peta pikiran. Hal ini menunjukkan bahwa terdapat perbedaan secara simultan kreativitas dan penguasaan kompetensi pengetahuan IPA siswa. Semakin tinggi kreativitas siswa dalam proses pembelajaran, maka semakin tinggi pula penguasaaan kompetensi pengetahuan IPA siswa. Sebaliknya, semakin rendah kreativias siswa terhadap proses pembelajaran maka semakin rendah pula penguasaan kompetensi pengetahuan IPA siswa. Sehingga dapat dikatakan terdapat perbedaan secara simultan kreativitas dan penguasaan kompetensi pengetahuan IPA siswa. 


\section{Simpulan dan Saran}

Berdasarkan pemaparan diatas dapat ditarik simpulan yaitu. 1) Terdapat pengaruh yang signifikan model pembelajaran SAVI bermuatan peta pikiran dengan siswa yang tidak mengikuti model pembelajaran SAVI bermuatan peta pikiran terhadap kreativitas siswa kelas V SD Gugus Singasari Kecamatan Pekutatan Tahun Pelajaran 2018/2019. Rata-rata nilai kreativitas yang dibelajarkan dengan model pembelajaran SAVI bermuatan peta pikiran sebesar 83,73 dan rata-rata kreativitas yang tidak mengikuti model pembelajaran SAVI bermuatan peta pikiran sebesar 74,14. Dari hasil uji Anava satu jalur juga dapat diketahui bahwa diperoleh nilai $\mathrm{F}$ hitung $=22,7$. Dengan demikian kreativitas siswa yang mengikuti model pembelajaran $S A V I$ bermuatan peta pikiran lebih baik dibandingkan dengan yang tidak mengikuti model pembelajaran SAVI bermuatan peta pikiran. 2) Terdapat pengaruh yang signifikan model pembelajaran SAVI bermuatan peta pikiran dengan siswa yang tidak dibelajarkan dengan model pembelajaran SAVI bermuatan peta pikiran terhadap penguasaan kompetensi pengetahuan IPA siswa kelas V SD Gugus Singasari Kecamatan Pekutatan Tahun Pelajaran 2018/2019. Rata-rata nilai kreativitas yang dibelajarkan dengan model pembelajaran $S A V I$ bermuatan peta pikiran sebesar 89,83 dan rata-rata penguasaan kompetensi pengetahuan IPA yang yang tidak mengikuti model pembelajaran SAVI bermuatan peta pikiran sebesar 74,86. Dari hasil uji Anava satu jalur juga dapat diketahui bahwa $\mathrm{F}$ hitung $=70,44$. Dengan demikian penguasaan kompetensi pengetahuan IPA siswa yang dibelajarkan dengan model pembelajaran SAVI bermuatan peta pikiran lebih baik dibandingkan dengan yang tidak mengikuti model pembelajaran SAVI bermuatan peta pikiran. 3) Terdapat pengaruh yang simultan model pembelajaran SAVI bermuatan peta pikiran terhadap kreativitas dan penguasaan kompetensi pengetahuan IPA siswa kelas V SD Gugus Singasari Kecamatan Pekutatan Tahun Pelajaran 2018/2019. Sesuai hasil analisis nilai rata-rata kreativitas pada siswa yang mengikuti model pembelajaran $S A V I$ bermuatan peta pikiran lebih tinggi dibandingkan siswa yang tidak megikuti model pembelajaran $S A V I$ bermuatan peta pikiran. Hal ini berarti antara kreativitas dan penguasaan kompetensi pengetahuan IPA siswa mengalami peningkatan, atau adanya peningkatan rata-rata nilai kreativitas dan nilai penguasaan kompetensi pengetahuan IPA siswa secara simultan setelah mengikuti model pembelajaran SAVI bermuatan peta pikiran.

Berdasarkan pemaparan simpulan diatas, maka dapat diajukan beberapa saran yaitu. 1) Kepada guru disarankan agar menerapakan model pembelajaran SAVI bermuatan peta pikiran karena hasil penelitian membuktikan bahwa penggunaan model pembelajaran SAVI bermuatan peta pikiran mampu meningkatkan kreativitas dan penguasaan kompetensi pengetahuan IPA siswa. 2) Kepada kepala sekolah agar dapat menggunakan hasil penelitian ini sebagai bahan acuan pedoman untuk membimbing guruguru dalam melaksanakan pembelajaran dengan menggunakan model pembelajaran untuk meningkatkan kreativitas dan penguasaan kompetensi siswa. 3) Kepada peneliti lain agar hasil penelitian ini dapat digunakan sebagai acuan kepustakaan untuk melakukan penelitian dalam variabel yang sama ataupun pada variabel yang berbeda.

\section{Daftar Rujukan}

Arini, N. W. (2012). Impelementasi Metode Peta Pikiran Berbantuan Objek Langsung untuk Meningkatkan Keterampilan Menulis Deskripsi. ". Journal Pendidikan Dan Pengajaran, 45(1).

Aris, S. (2014). Model pembelajaran Inovatif Dalam Kurikulum 2013. In 1 (Issue). Yogyakarta: AR-ruz media.

Atmaja. (2017). Pengaruh Model Pembelajaran SAVI Terhadap Nilai Karakter PKn Siswa Kelas V SD. Mimbar PGSD Universitas Pendidikan Ganesha, 5(1).

Ayu, I. G., Perdani, M., Gading, K., \& Riastini, P. N. (2016). Pengaruh Model Pembelajaran Word Square Terhadap Hasil Belajar IPA Pada Siswa Bermotivasi Belajar Berbeda di Kelas IV SD. E-Journal PGSD Universitas Pendidikan Ganesha, 4(1-10).

Budiarti, Y. (2015). Pengembangan Kemampuan Kreativitas Dalam Pembelajaran. PROMOSI (Jurnal Pendidikan Ekonomi), 3(1), 61-72. https://doi.org/10.24127/ja.v3i1.143

Carito, Rohim, D. (2013). Penerapan Pendekatan SAVI (Somatis Auditori Visual Intelektual) Untuk Meningkatkan Kreativitas Dalam Pembelajaran Matematika Volume Bangun Ruang. Jurnal Fkip UNES, 1(1).

Dewi, N. L. P. K. (2013). Pengaruh Model Pembelajaran PDEODE TerhadaP Kemampuan Berpikir Kreatif dalam Pembelajaran IPA Siswa Kelas V SD Laboratorium UNDIKSHA. Skripsi (tidak diterbitkan). 
Singaraja: Universitas Pendidikan Ganesha.

Haruminati, Y. (2016). Pengaruh Model Pembelajaran SAVI Terhadap Minat Belajar Matematika Siswa Kelas IV SD Mutiara Singaraja. E-Journal PGSD Universitas Pendidikan Ganesha, 4(1).

Putrayasa. (2014). Pengaruh Model Pembelajaran Discovery Learning dan Minat Belajar Terhadap Hasil Belajar IPA Siswa. Jurnal Mimbar PGSD Universitas Pendidikan Ganesha, 2(1).

Silberman, M. (2013). Pembelajaran Aktif 101 Strategi untuk Mengajar Secara Aktif. PT Indeks.

Simatupang, N. (2016). Meningkatkan Aktivitas dan Kreativitas Mahasiswa Jurusan Pendidikan Jasmani dan Olahraga. Journal Pedagogik Keolahragaan, 2(2).

Widura, S. (2016). Mind Map Langkah Demi Langkah. PT Elex Media Komputindo.

Yudiari, M. (2016). Pengaruh Model Pembelajaran SAVI Berbantuan Media Mind Mapping Terhadap Hasil Belajar IPA Siswa Kelas V SD di Gugus II Kecamatan Mendoyo. E-Journal PGSD Universitas Pendidikan Ganesha, 3(1). 